\title{
Sleep deprivation and diet affect human GH gene expression in transgenic mice in vivo
}

\author{
Jessica S Jarmasz ${ }^{1}$, Yan Jin ${ }^{1}$, Hana Vakili ${ }^{2}$ and Peter A Cattini ${ }^{1}$ \\ ${ }^{1}$ Department of Physiology \& Pathophysiology, Max Rady College of Medicine, Rady Faculty of Health Sciences, University of Manitoba, Winnipeg, \\ Manitoba, Canada \\ 2Department of Pathology, University of Texas Southwestern Medical Center, Dallas, Texas, USA
}

Correspondence should be addressed to J S Jarmasz: Jessica.Jarmasz@umanitoba.ca

\begin{abstract}
Human (h) growth hormone (GH) production studies are largely limited to effects on secretion. How pituitary hGH gene ( $h G H-N / G H 1)$ expression is regulated is important in our understanding of the role hGH plays in physiology and disease. Here we assess for the first time the effect of sleep deprivation (SD) and high-fat diet (HFD) on hGH-N expression in vivo using partially humanized $171 \mathrm{hGH} / \mathrm{CS}$ transgenic (TG) mice, and attempted to elucidate a role for DNA methylation. Activation of $h G H-N$ expression requires interactions between promoter and upstream locus control region (LCR) sequences including pituitary-specific hypersensitive site (HS) I/II. Both SD and diet affect hGH secretion, but the effect of SD on $h G H-N$ expression is unknown. Mice fed a HFD or regular chow diet for 3 days underwent SD (or no SD) for $6 \mathrm{~h}$ at Zeitgeber time (ZT) 3. Serum and pituitaries were assessed over $24 \mathrm{~h}$ at 6-h intervals beginning at ZT 14. SD and HFD caused significant changes in serum corticosterone and insulin, as well as $h G H$ and circadian clock-related gene RNA levels. No clear association between DNA methylation and the negative effects of SD or diet on hGH RNA levels was observed. However, a correlation with increased methylation at a CpG (cytosine paired with a guanine) in a putative E-box within the hGH LCR HS II was suggested in situ. Methylation at this site also increased BMAL1/CLOCK-related nuclear protein binding in vitro. These observations support an effect of SD on hGH synthesis at the level of gene expression.
\end{abstract}

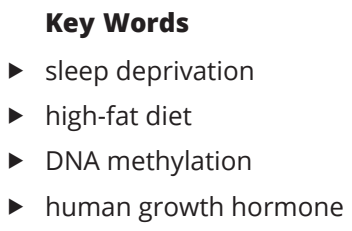

Endocrine Connections (2020) 9, 1135-1147

\section{Introduction}

Human (h) growth hormone (GH) is synthesized and secreted in a pulsatile manner by somatotrophs located in the anterior pituitary (1). Following the successful isolation and purification of hGH in 1944, GH secretion in humans has been heavily studied (2). Serum levels of hGH vary considerably over the course of the day and during the night as it is dependent on a variety of factors including (and not limited to) the circadian rhythm, sleep-wake cycle, diet, metabolism, age and sex $(1,3,4)$. Typically, hGH secretion peaks shortly after sleep onset during the slow-wave sleep stage of non-rapid eye movement sleep. Sleep deprivation (SD) can result in the suppression of hGH nocturnal peaks where increases in GH secretion can occur during the day as a way to compensate $(3,4,5)$. Diet and exercise are also known to affect serum hGH levels. Hypersecretion of $\mathrm{GH}$ is observed in humans during prolonged reductions in food intake, resulting in dramatic decreases in body weight and fat mass (3), whereas the opposite is observed with excess caloric intake. Reduced hGH serum levels as well as hyperinsulinemia are seen in individuals with obesity $(6,7)$. During both aerobic and resistance exercise, hGH secretion is increased (1). In addition, increased food intake and decreased physical activity as well as inadequate sleep are considered risk factors for obesity as well as insulin resistance and diabetes in humans $(6,8)$. 
While the effect of SD on hGH serum levels has been described $(4,9)$, there is no description of the effect on hGH synthesis and specifically gene expression. This is due to difficulties and confounding variables associated with sampling normal human pituitaries in vivo. As such, studies of hGH production are limited largely to measurement of serum levels and thus effects on secretion (protein). This situation has been remedied in part by the development of partially humanized 171hGH/CS transgenic (TG) CD-1 mice, which include a single copy of the intact hGH gene $(h G H-N / G H 1)$ locus $(10,11)$. This 171 kilobase $(\mathrm{kb})$ transgene located on mouse chromosome 14 contains $h G H-N$ and locus control region (LCR) which is marked by the presence of nuclease hypersensitive sites (HS) I-V, with HS I/II exclusively regulating $h G H-N$ expression. The LCR is located $14-32 \mathrm{~kb}$ upstream of the $h G H-N$ promoter, where interaction between the two regions is critical for pituitary- and cell-specific activation of the gene $(11,12)$. The $171 \mathrm{hGH} / \mathrm{CS}$ TG mice were used previously to assess the effect of an acute 3-day high-fat diet (HFD) on daily rhythmic hGH secretion and synthesis (13). Levels of $h G H-N$ RNA displayed a circadian pattern by oscillating over a 24 -h time frame that was disrupted by a HFD vs a regular control chow diet (RCD) at Zeitgeber time (ZT) 2. By contrast, mouse GH did not display a clear rhythmic pattern over $24 \mathrm{~h}$ or an effect of diet under the conditions and times of assessment (13).

HFD-induced obesity in mice is reported to disrupt circadian rhythms $(14,15)$. Expression of genes coding for the evolutionarily conserved circadian rhythm-related transcription factors were also assessed in $171 \mathrm{hGH} / \mathrm{CS}$ TG mice on an acute 3-day HFD (13). Brain and Muscle ARNT-Like 1 (BMAL1) and Circadian Locomotor Output Cycles Kaput (CLOCK) gene products heterodimerize (BMAL1/CLOCK) and bind enhancer (E)-box elements to transactivate the Period Circadian Regulator 1-3 (PER1-3) and Cryptochrome Circadian Regulator 1 and 2 (CRY 1 and 2) genes $(16,17)$. PER and CRY gene products bind together to form a complex which then binds chromatin to inhibit BMAL1 and CLOCK activity, and subsequently represses PER and CRY gene expression which in turn creates a negative feedback loop $(16,17)$. BMAL1/CLOCK can also activate the nuclear orphan receptor genes coding for REV-ERB $\alpha / \beta$ and retinoid-related orphan nuclear receptor alpha/beta $(\mathrm{ROR} \alpha / \beta)$, which have opposing actions on BMAL1 expression in order to ensure rhythmic expression (17). An E-box element containing the core sequence 5'-CACGTG-3' was identified within the $h G H-N$ promoter but is not found within the mouse $G h$ promoter. This core sequence enables binding of BMAL1/CLOCK heterodimer to the $h G H-N$ promoter, where association of BMAL1 with this region was reduced as a result of HFD in $171 \mathrm{hGH} / \mathrm{CS}$ TG mice (13).

The circadian clock genes are also known to be involved in the homeostatic sleep process. The sleep homeostat keeps track of the time spent awake and asleep, where loss of sleep is typically followed by increased sleep (18). The joint action of the sleep homeostat and circadian processes controls sleep inclination, duration, and quality of wakefulness. Misalignment of both of these processes is experienced by humans during jet-lag and as a result of shift work $(18,19)$. SD is when an individual does not get enough sleep, which results in wide-spread disturbances in the body and brain. SD has been shown to affect mouse whole brain Per2 expression $(19,20)$ as well as reduce DNA binding of BMAL1/CLOCK heterodimer (21). In addition, individuals with obesity typically suffer sleep loss (22).

Epigenetics represents the chemical modifications made to chromatin that influence gene expression (23). The methylation of cytosine paired with a guanine $(\mathrm{CpG})$ termed 'DNA methylation' is one of the many epigenetic mechanisms that govern gene expression where approximately $70-80 \%$ of $\mathrm{CpG}$ dinucleotides are methylated (23). The putative BMAL1/CLOCK binding E-box element located in the $h G H-N$ promoter ( $5^{\prime}$-CACGTG-3') contains a CpG site, and thus also represents a potential target for DNA methylation as a result of sleep or diet disturbances. Several genome-wide methylation studies have observed changes in methylation in obesity-, SD- and Clock-related genes $(24,25,26,27)$. Whether modification of the $h G H-N$ promoter E-box occurs in response to SD or diet, and/or whether DNA methylation alters E-box factor binding, and specifically association related to BMAL1/CLOCK, is not known. Thus, here we investigated for the first time the acute effect of a 6-h period of SD and an acute 3 -day HFD on $h G H-N$ expression in the daily cycle. This has been pursued for possible involvement of epigenetic changes in CpG methylation status associated with the $h G H-N$ promoter and LCR HS I/II.

\section{Methods}

\section{Animals and diet}

Ethical animal use approval was obtained from Central Animal Care Services (Protocol \#19-042 and \#15-036/1/2) at the University of Manitoba. Mice were housed in an environmentally controlled room maintained on a $12 \mathrm{~h}$ light/12 h darkness cycle (06:00 h/18:00 h; ZT 0/ZT 12).

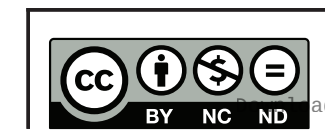


Access to tap water and food in the form of palatable pellets was ad libitum. Male 3-4 week old $171 \mathrm{hGH} / \mathrm{CS}$ TG CD-1 mice were used since growth hormone levels are at their highest during puberty (onset at days 21-35) (28). Mice were randomly assigned to receive RCD (fat $14 \mathrm{kcal} \%$, carbohydrate $60 \mathrm{kcal} \%$, and protein 25 kcal\%; Prolab® RHM 3000 5P00*) or HFD (fat $60 \mathrm{kcal} \%$, carbohydrate $20 \mathrm{kcal} \%$, and protein $20 \mathrm{kcal} \%$; Research Diets D12492). Mice were fed starting in the afternoon of day 1 for 3 full days before being sacrificed every $6 \mathrm{~h}$ by cervical dislocation, starting at ZT $14(20: 00 \mathrm{~h})$ on day 3 of diet and then subsequently at ZT $20(02: 00 \mathrm{~h})$, and then ZT $2(08: 00 \mathrm{~h})$, ZT 8 (14:00 h) and ZT 14 on day 4 to represent a full 24-h cycle to assess circadian effects. Combined assessment of ZT 14-20 and ZT 2-8 were used to generate values for the dark/active and light/inactive phases of the daily cycle for mice, respectively. SD was effectuated on the morning of day 3 of receiving the diets for a total of $6 \mathrm{~h}$, before being allowed to settle and sleep. Cages were removed from the holding rack, opened, and animals were disrupted by moving various cage components (nest, food tray) from one side of the cage to the other, as well as being stroked or handled briefly every 30 min starting at ZT $3(29,30)$. Body weights were taken prior to and after diet intervention before sacrificing. The amount of food consumed over the 3-day period was also recorded. Average (mean \pm S.E.M.) starting body weight for each group of mice was $23.95 \pm 0.27 \mathrm{~g}$ for the no sleep deprivation group $(n=140)$ and $25.54 \pm 0.25 \mathrm{~g}$ for the sleep-deprived group $(n=90)$.

\section{Blood and tissue collection}

After cervical dislocation and decapitation, trunk blood was collected and allowed to clot for $\geq 10 \mathrm{~min}$. The cranium was opened and the pituitary gland was removed, flash-frozen immediately, and stored at $-80^{\circ} \mathrm{C}$. Serum was separated by centrifugation at $9300 \boldsymbol{g}$ for $10 \mathrm{~min}$ in a microcentrifuge at $4^{\circ} \mathrm{C}$, then aliquoted and stored at $-80^{\circ} \mathrm{C}$. Serum insulin and corticosterone levels were detected by ELISA according to manufacturer instructions (Rat/Mouse
Insulin, EZRMI-13K, Millipore; DetectX Corticosterone Enzyme Immunoassay Kit, K014-H5, Arbor Assays).

\section{Quantitative realtime RT-PCR (qPCR)}

RNA was extracted from pituitaries using the RNeasy ${ }^{\circledR}$ Plus Mini Kit 250 (REF \#74136) with the Qiagen QIA Shredder ${ }^{\mathrm{TM}} 250$ (REF \#79656) according to manufacturer instructions. Pituitaries were homogenized by a pestle and mortar for 40-60 s followed by a 5-min incubation. This was repeated three times before continuing with the extraction. Average RNA yield was 4725 ng (s.E.M. \pm 319.7 ) and 4942 ng (s.E.M. \pm 368.7 ) for RCD and HFD (respectively). RNA (1-2 $\mu \mathrm{g})$ was reverse transcribed into cDNA using the QuantiTect RT Kit (205314; Qiagen) in the MJ Research PTC-100 $10{ }^{\text {TM }}$ Programmable Thermal Controller. RT negative samples contained sterile distilled water instead of RT enzyme. cDNA samples were then diluted to 0.02 $\mu \mathrm{g} / \mu \mathrm{L}$ and amplified in the Applied Biosystems 7500 Fast Real-Time PCR system with specific forward and reverse primers $((0.5 \mathrm{pM}) ; 1 \mu \mathrm{L}$ each) manufactured by Integrated DNA Technologies (Table 1) and with Power SYBR® Green PCR Master Mix (10 $\mu \mathrm{L}$; \#4367659, Thermo Fisher Scientific). cDNA was denatured at $95^{\circ} \mathrm{C}(5 \mathrm{~min})$, followed by 40 cycles of denaturing at $95^{\circ} \mathrm{C}(15 \mathrm{~s})$, annealing at $60^{\circ} \mathrm{C}(15 \mathrm{~s})$, and $72^{\circ} \mathrm{C}(30 \mathrm{~s})$. The gene expression level in each sample was calculated from a standard curve and normalized to $\beta$-actin as the reference gene. qPCR was run in duplicate and on four to six independent samples per timepoint for each set of primers.

Minus RT samples were also produced and subjected to RT-PCR and qPCR with the same conditions as above with forward and reverse primers for mouse growth hormone $(m G h)$ to control for genomic DNA contamination and to assess technique (results not shown).

\section{DNA extraction and targeted bisulfite sequencing}

Genomic DNA from pituitaries was extracted using the DNeasy Blood and Tissue Kit (\#69506, Qiagen) according

Table 1 List of human (h) and mouse $(m)$ forward and reverse primer sequences used in this study.

\begin{tabular}{l} 
Primer \\
\hline $\mathrm{hGH}$ \\
$\mathrm{mGH}$ \\
$\mathrm{m} \beta$-Actin \\
mBmal1 \\
mClock \\
mPer2 \\
mCry1
\end{tabular}

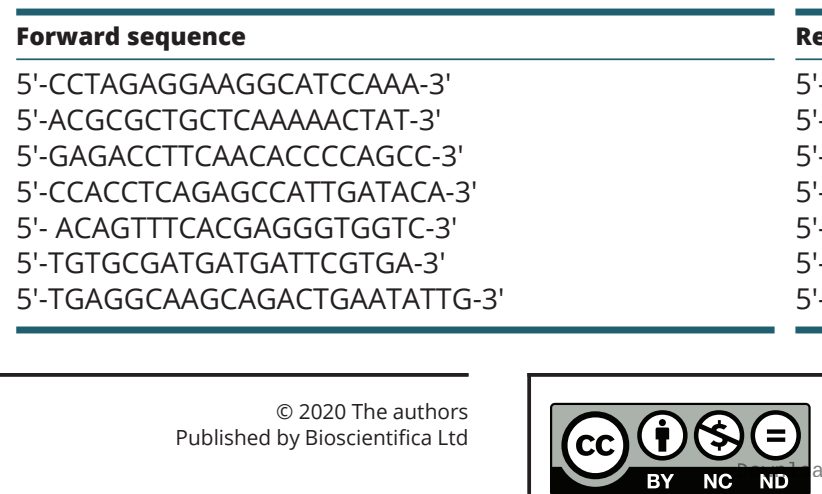

Reverse sequence

5'-GCAGCCCGTAGTTCTTGAGTAG-3'

5'-CACAGGAGAGTGCAGCAGAG-3'

5'-GGAGAGCATAGCCCTCGTAG-3'

5'-GAGCAGGTTTAGTTCCACTTTGTCT-3'

5'-TCCCTACCGTCTCATCAAGG-3'

5'-GGTGAAGGTACGTTTGGTTTGC-3' 5'-CCTCTGTACCGGGAAAGCTG-3'
This work is licensed under a Creative Commons Attribution-NonCommercial-NoDerivatives 4.0 internationad bicense.ifica.com at 04/26/2023 12:04:49PM 
to manufacturer instructions. Briefly, pituitaries were allowed to digest overnight in lysis buffer in a $56^{\circ} \mathrm{C}$ water bath before subjected to extraction. Average DNA yield was 1187 ng (s.E.M. \pm 77.4) and 1156 ng (s.E.M. \pm 77.4) for RCD and HFD (respectively). Extracted DNA was used for targeted bisulfite sequencing including primer design, validation, target amplification and sequencing which was performed by Zymo Research Corporation (Irvine, CA).

Primer pairs were designed with Rosefinch in order to target CpG sites in the specified regions of interest (ROI) within the $h G H-N$ promotor and LCR hypersensitive site II (HS II). Design parameters were chosen such that PCR amplicons would be ideally $>100$ to $<300 \mathrm{bp}$, and the primers avoided annealing to $\mathrm{CpG}$ sites at the region of interest to the maximum extent possible. In the event that CpG sites were absolutely necessary for target amplification, ordered primers were synthesized with a pyrimidine $(\mathrm{C}$ or T) at the CpG cytosine in the forward primer, or a purine (A or $\mathrm{G}$ ) in the reverse primer to minimize amplification bias to either the methylated or unmethylated allele. All primers in TE solution at $(100 \mu \mathrm{M})$ were diluted to $2 \mu \mathrm{M}$ each and tested using Real-Time PCR with $1 \mathrm{ng}$ of bisulfiteconverted control DNA (duplicate individual reactions).

Genomic DNA samples from pituitaries were subjected to sodium bisulfite treatment using the EZDNA MethylationLightning ${ }^{\mathrm{TM}}$ Kit (Zymo Research Corp., D5030) according to the manufacturer's instructions. Bisulfite-treated samples (5 ng) and validated primer pairs were subjected to targeted amplification, purification (ZR-96 DNA Clean \& Concentrator $\left.{ }^{\mathrm{TM}}, \mathrm{D} 4023\right)$, and prepared for sequencing using a MiSeq V2 300 bp Reagent Kit (Illumina) and pairedend sequencing protocol according to the manufacturer's guidelines. Sequence reads from bisulfite-treated libraries were identified using the standard Illumina base-calling software and then analyzed using Zymo Research Corp.'s proprietary analysis pipeline. Sequence reads were aligned to the reference genome assembly hg38 using Bismark (http://www.bioinformatics.babraham.ac.uk/projects/ bismark/). The methylation level of each sampled cytosine was estimated as the number of reads reporting a $\mathrm{C}$, divided by the total number of reads reporting a $\mathrm{C}$ or $\mathrm{T}$. The data shown ( $n=2$ samples per group) represents methylation ratios; the measured number of methylated cytosines divided by total number of cytosines covered at that site. Each sample consisted of four individual mouse pituitaries that were combined in order to provide sufficient amounts of genomic DNA for analysis.

\section{Electrophoretic mobility shift assay (EMSA)}

EMSA as well as human embryonic kidney (HEK) 293 cell culture, Bmal1/Clock plasmid transfection, and nuclear extract preparation have been described previously (13, 31). Briefly, HEK293 cells were cultured in Dulbecco's Modified Eagle Medium (DMEM; Invitrogen, 12100061) supplemented with fetal bovine serum (Gibco; REF \#12483-020) and antibiotic cocktail (50 $\mu \mathrm{g} / \mathrm{mL}$ streptomycin, $0.5 \mathrm{mM}$ glutamine, 50 units $/ \mathrm{mL}$ penicillin) and grown accordingly. Trans-IT293 reagent (Mirus Biol Corp., Madison, WI) diluted with serum-free DMEM as well as Bmal1/Clock expression vectors were used for transient transfection. The cDNA expression vectors for mouse Clock (Gal4-Clock/UA256), and Bmal1 (Gal4Bmal1/UA255) were kindly provided by Dr. Urs Albrecht (University of Fribourg, Fribourg, Switzerland) (32). EMSA was performed using nuclear extract (Nuclear Extraction kit (Abcam, ab113474)) from HEK293 cells either overexpressing Bmal1 and Clock, or an empty vector as a control together with ${ }^{32} \mathrm{P}$-labeled oligonucleotide probes which included unmethylated and methylated E-box or putative E-box DNA elements in the $h G H-N$ promoter and LCR HS II (Table 2). Briefly, $4 \mu \mathrm{g}$ of nuclear extract

Table 2 List of forward and reverse oligonucleotide sequence probes used for EMSA in this study.

Target
Human growth hormone promoter single site methylation
Hypersensitive site II single site methylation $(\mathrm{m})$ in E-box 1
Hypersensitive site II single site methylation (m) in E-box 2
Unmethylated human growth hormone promoter E-box

Unmethylated hypersensitive site II E-box 1

Unmethylated hypersensitive site II E-box 2

\begin{tabular}{|c|}
\hline Forward and reverse sequences \\
\hline $\begin{array}{l}\text { Forward: GGCACCCAmCGTGACCCTTAAA } \\
\text { Reverse: TTTAAGGGTCAmCGTGGGTGCC } \\
\text { Forward: CTTGGGGCACAmCGTGTTTGTGGGG } \\
\text { Reverse: CCCCACAAACAmCGTGTGCCCCAAG } \\
\text { Forward: TAAGAAGGAmCGTGGGTTTGAGTCC } \\
\text { Reverse: GGACTCAAACCCAmCGTCCTTCTTA } \\
\text { Forward: GGCACCCACGTGACCCTTAAA } \\
\text { Reverse: TTTAAGGGTCACGTGGGTGCC } \\
\text { Forward: CTTGGGGCACACGTGTTTGTGGGG } \\
\text { Reverse: CCCCACAAACACGTGTGCCCCAAG } \\
\text { Forward: TAAGAAGGACGTGGGTTTGAGTCC } \\
\text { Reverse: GGACTCAAACCCACGTCCTTCTTA }\end{array}$ \\
\hline
\end{tabular}

This work is licensed under a Creative Commons Attribution-NonCommercial-NoDerivatives 4.0 elnternationab dicense ifica.com at 04/26/2023 12:04:49PM 
was incubated with EMSA buffer containing $2 \mu \mathrm{g}$ of poly(dI-dC) for $5 \mathrm{~min}$. The radiolabeled oligonucleotide probes ( $1 \mathrm{ng}$ ) were then added, and the reactions were incubated for a further $20 \mathrm{~min}$ at room temperature. Retardation of DNA-protein complexes were resolved in non-denaturing 5\% (w/v) polyacrylamide gels and visualized by autoradiography.

\section{Statistical analysis}

All data were subjected to statistical analysis utilizing GraphPad Prism 8 Software (Version 8.4.2 (679)). Any value that was more than \pm two standard deviations from the mean was considered an outlier and removed from analysis. A non-parametric t-test (Mann-Whitney) was used for single comparisons and $P$-values were adjusted using the Benjamini-Hochberg procedure using the formula $\left((\mathrm{i} / \mathrm{m})^{\star} \mathrm{Q}\right)$ and a false discovery rate (FDR) of 0.1 . Adjusted $P$-values are shown and significance is marked by ${ }^{*} P<0.05,{ }^{* *} P<0.01$, or ${ }^{* *} P<0.001$, and trends were marked by ${ }^{\dagger} P<0.075$. All error bars represent the s.E.M.

\section{Results}

\section{Acute SD affects weight gain and food intake}

The effect of acute SD on $h G H-N$ RNA levels in dark/ active and light/inactive phases of the daily cycle, as well as the possible influence of diet (HFD vs RCD), was assessed beginning at ZT 14-20 (dark/active phase) and finishing at ZT 2-8 (light/inactive phase). There was no significant difference in weight gain $(P=0.2188)$ or food intake $(P=0.1731)$ for mice fed a HFD vs RCD for 3 days (Table 3A and B).

During the light/inactive phase at ZT 3, mice were subjected to $6 \mathrm{~h}$ of gentle handling to cause acute SD. Sleep-deprived mice displayed characteristic behavior during the 30-min intervals of maintained wakefulness. At the start, males would resist handling, continuously explore their cage with vigor, hide in their nest, and sample their food. After $2 \mathrm{~h}$, mice started to display signs of SD. There was less resistance when being handled. Mice began sleeping out of the nest, and at times not huddled together as normally observed. Acute SD had significant effects on weight (decrease) and food intake (increase) among both diets (Table $3 \mathrm{~A}$ and $\mathrm{B}$ ). Total serum corticosterone levels increased 2.1-fold in both diets in the active phase which was $\sim 4$ to $10 \mathrm{~h}$ after SD ended (Fig. 1A). This increase was only significant in RCD mice

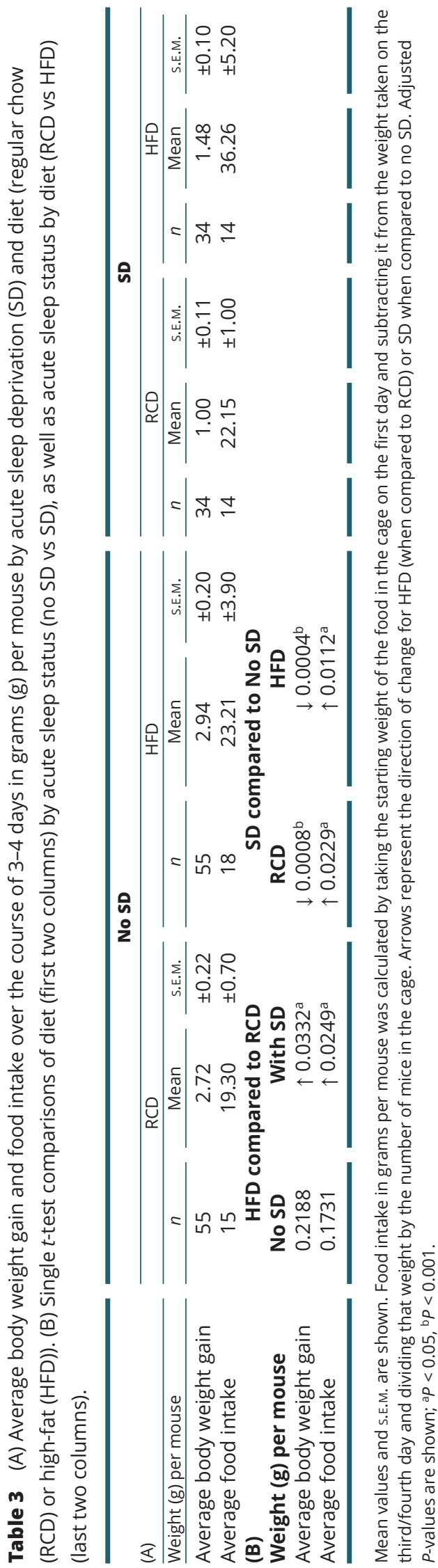



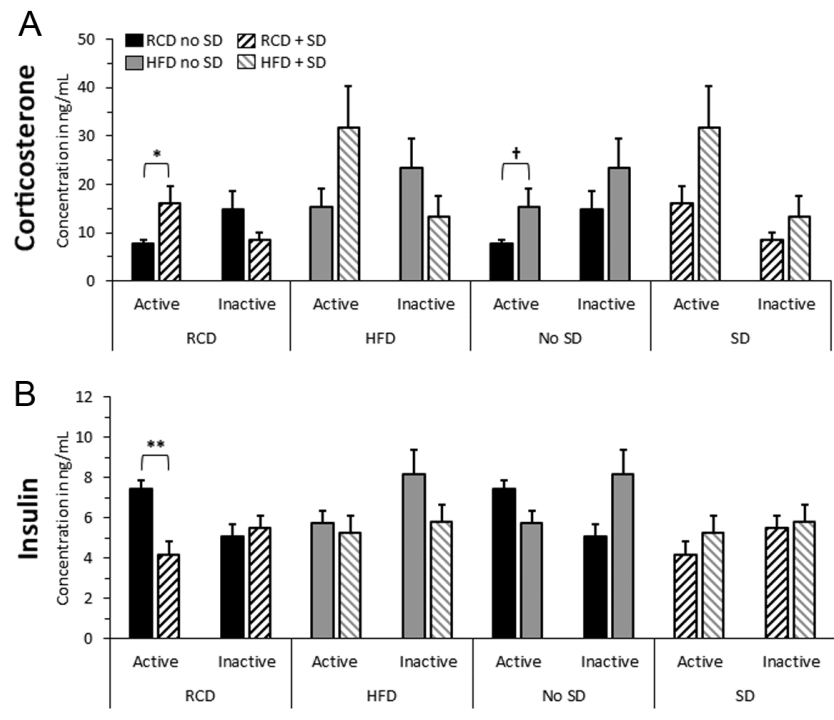

\section{Figure 1}

Serum concentrations in $\mathrm{ng} / \mathrm{mL}$ of $(\mathrm{A})$ corticosterone and $(B)$ insulin by diet and acute sleep deprivation (SD) during the dark/active (Zeitgeber time (ZT) $14+20$ ) and light/inactive (ZT $2+8)$ phases. Active phase represents serum sampling at $\sim 4$ to $10 \mathrm{~h}$ after SD ended, and inactive phase represents serum sampling at $\sim 16$ to $20 \mathrm{~h}$ after SD ended. Solid-filled bars represent no SD and diagonal pattern fill represents with SD. Black represents regular chow diet (RCD) while gray represents high-fat diet (HFD). $n=7-10$ per group. Mean values and S.E.M. are shown. Eight single $t$-test comparisons were effectuated to compare no SD vs SD and RCD vs HFD. A trend is represented by $t P<0.075$ and significance is represented by $* P<0.05, * * P<0.01$.

$(P=0.0468, n=8,10)$ and was accompanied by a $44.3 \%$ decrease in serum insulin levels $(P=0.0048, n=9)$ (Fig. 1B). These effects were no longer detectable in the inactive phase which was $\sim 16$ to $22 \mathrm{~h}$ after SD ended (Fig. 1A and B). By contrast, the apparent 2.1-fold increase in serum corticosterone levels in the active phase in HFD mice was not significant ( $P=0.2648, n=7,8)$ (Fig. 1A). No effect of acute SD in HFD mice on serum insulin was detected in either the active or inactive phases after SD (Fig. 1B).

\section{Acute SD and diet affect Bmal1, Per2 and $h G H-N$ RNA levels}

Expression of circadian rhythm-related transcription factor genes, including Bmal1, Clock, Cry1 and Per2, were assessed over $24 \mathrm{~h}$, beginning at ZT 14 in mice fed a RCD and HFD (Fig. 2). Opposing oscillations of Bmal1 and Per2 RNA levels were seen with a peak and trough in the light/inactive phase (respectively) with both diets (Fig. 2), consistent with the presence of a daily cycle in the mouse pituitary. Under the time and conditions of assessment, no obvious changes were seen in clock-related gene RNA levels (Fig. 2).

Sleep loss is reported to reduce DNA binding of BMAL1/CLOCK in mouse brain (19) and, thus, may negatively affect $\mathrm{Cry} / \mathrm{Per}$ RNA transcript levels. Given the opposing rhythmic patterns of Bmal1 and Per2 RNA levels observed (Fig. 2), the effect of SD during the dark/active and light/inactive phases among mice fed a RCD vs HFD was assessed (Fig. 3). For RCD, no significant decrease in Bmal1 RNA levels was detected with acute SD. However, a $37.7 \%$ decrease was observed in HFD mice after acute SD during the dark/active phase, but this was not significant $(P=0.2552 ; n=9,10)$. A decrease in Per2 RNA levels was suggested in RCD mice after acute SD during the dark/ active phase, while a significant decrease was detected in the light/inactive phase $(52.6 \%, P=0.0076)$. Significant reductions in Per2 transcript levels were also seen in HFD mice after acute SD in the dark/active phase $(43.8 \%$, $P=0.0106)$ and light/inactive phase $(54.4 \%, P=0.0420)$ of the daily cycle (Fig. 3).

GH synthesis and secretion also follow a circadian and diurnal rhythm, and levels are known to be affected by diet $(6,13)$. A significant decrease in relative RNA levels of $h G H-N$ but not $m G h$ transcript levels was observed during the dark/active phase (ZT $14+20 ; 74.6 \%, P=0.0284, n=9$,

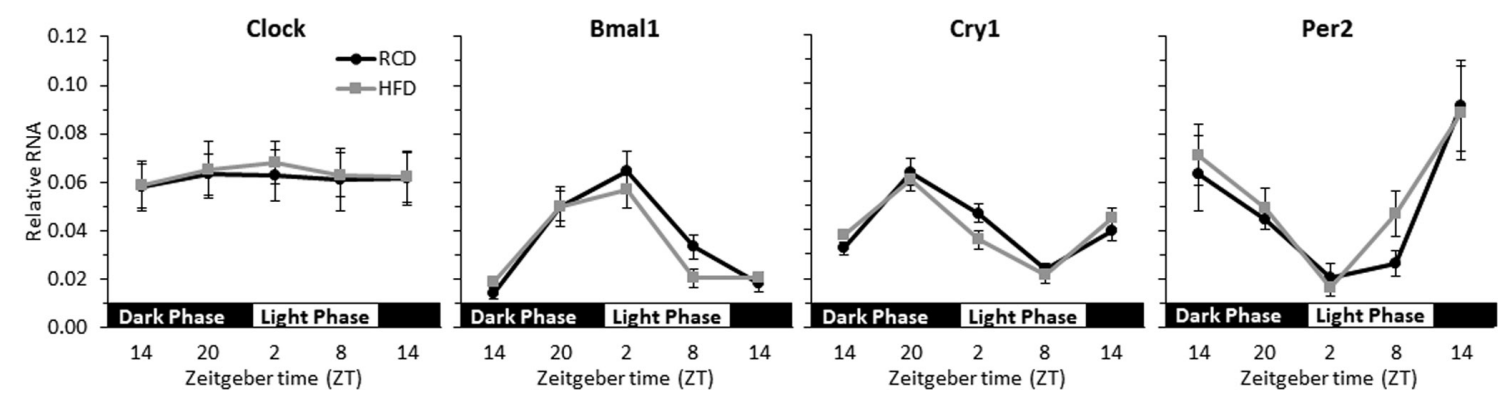

Figure 2

The effect of diet on mouse circadian rhythm transcription factors. Clock, Bmal1, Cry1 and Per2 RNA transcript levels normalized to $\beta$-actin RNA and shown as relative RNA across a 24-h cycle beginning $2 \mathrm{~h}$ into the dark/active phase (Zeitgeber time (ZT) 14=20:00 h). Black line represents regular chow diet (RCD) and gray line represents high-fat diet (HFD). $n=4,5$ per timepoint. Mean values and S.E.M. are shown.

https://ec.bioscientifica.com https://doi.org/10.1530/EC-20-0354 (c) 2020 The authors Published by Bioscientifica Ltd

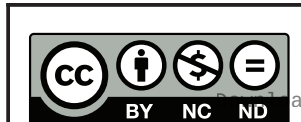

This work is licensed under a Creative Commons Attribution-NonCommercial-NoDerivatives 4.0 elnternationad dicense.ifica . com at $04 / 26 / 2023 \quad 12: 04: 49 \mathrm{PM}$ 

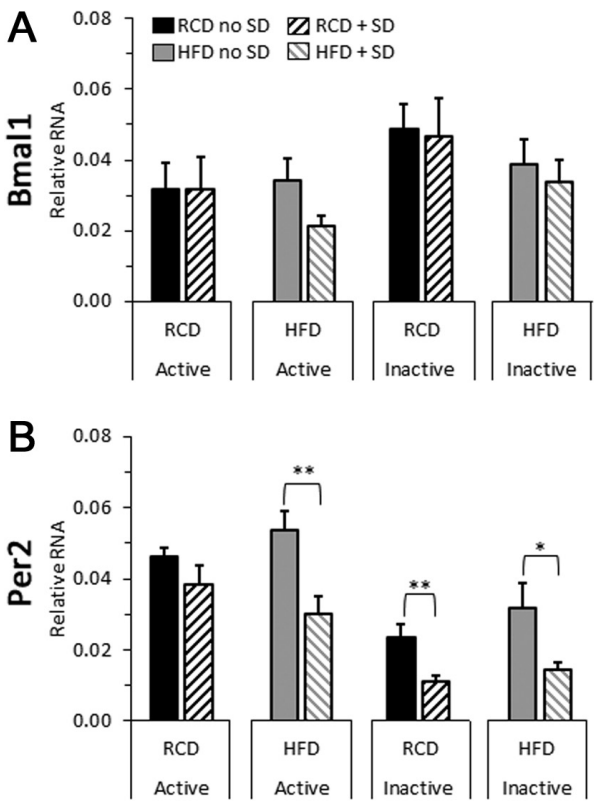

Figure 3

The effect of acute sleep deprivation (SD) on mouse circadian rhythmrelated transcriptions factors (A) Bmal1 and (B) Per2 RNA levels during the dark/active (Zeitgeber time (ZT) 14-20) and light/inactive (ZT 2-8) phases in both regular control chow (RCD) and high-fat (HFD) diets. Bmal1 and Per2 RNA transcript levels normalized to $\beta$-actin RNA and shown as relative RNA. $n=9,10$ per timepoint. Mean values and S.E.M. are shown. Four single $t$-test comparisons were effectuated to compare no SD vs SD. Significance is represented by $* P<0.05, * * P<0.01$.

10) in $171 \mathrm{hGH} / \mathrm{CS}$ TG mice fed a HFD vs RCD. A $57.9 \%$ decrease was observed during the light/inactive phase (ZT $2+8)$ but this was not significant $(P=0.1128, n=9,10)$ (Fig. 4A and B). This is similar to a previous report, which found a significant decrease in $h G H-N$ RNA levels during (ZT 2) but not throughout (ZT 6 or 10) the light/inactive phase, when comparing control diet to HFD (13). Acute SD was also associated with comparable reductions in $h G H-N$ RNA transcript levels in mice fed a RCD but not HFD, during both dark/active $(64.5 \%, P=0.0284, n=9)$ and light/inactive $(49.0 \%, P=0.0699, n=9,10)$ phases of the daily cycle (Fig. 4B).

Human GH RNA levels were also assessed over 24 $\mathrm{h}$, beginning at ZT 14 in mice fed a RCD and HFD (Fig. 5). Different diurnal oscillations are observed among both diets and acute SD status. Significant changes were observed with acute SD among RCD mice, particularly at ZT $14(P=0.0278)$ and ZT $8(P=0.0278)$. Among HFD mice, there is no obvious diurnal cycle and no significant differences with acute SD (Fig. 5), suggesting a disruption as a result of a HFD vs RCD with acute SD.
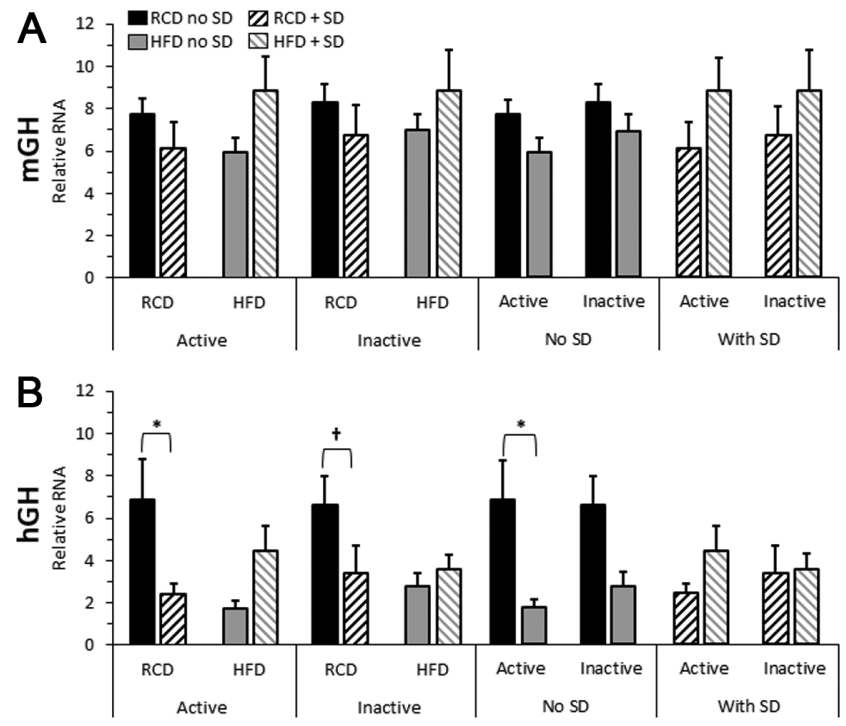

Figure 4

The effect of acute sleep deprivation (SD) on (A) mouse (m) and (B) human (h) growth hormone $(\mathrm{GH})$ during the dark/active (Zeitgeber time (ZT) $14+20)$ and light/inactive (ZT $2+8$ ) phases in both regular control chow (RCD) and high-fat (HFD) diets. RNA transcript levels for $m G h$ and $h G H-N$ normalized to $\beta$-actin RNA and shown as relative RNA. $n=9,10$ per timepoint. Mean values and S.E.M. are shown. Eight single $t$-test comparisons were effectuated to compare no SD vs SD and RCD vs HFD. A trend is represented by ${ }^{\dagger} P<0.075$ and significance is represented by $\star P<0.05$.

DNA methylation of E-box-related elements in the hGH-N promoter and LCR are associated with both increased and decreased clock-related transcription factor binding

Interaction between $h G H-N$ promoter and LCR HS I and II is required for efficient $h G H-N$ expression $(10,33)$. Binding of members of the E-box transcription factor family to a putative E-box element (underlined) within the $h G H-N$ proximal promoter region $-264 /-259(h G H-N$ promoter E-box, 5'-GCACCCACGTGACCCT-3'), has been suggested to modify this interaction (Fig. 6A) (13, 34). Specifically, changes in insulin-responsive hypoxiainducible factor $\alpha$ (HIF-1 $\alpha$ ) binding in vitro and BMAL1/ CLOCK heterodimer binding in situ have been linked to negative effects of HFD and excess insulin on $h G H-N$ expression $(13,34)$. Examination of LCR HS I/II identified two putative E-box-like DNA elements specifically in HS II and outside the sequences encompassing HS I (35). Like the $h G H-N$ promoter E-box element, both 5'-GGGCACACGTGTTTGTG-3' (HS II E-box 1) and 5'-AGAAGGACGTGGGTTTG-3' (HS II E-box 2) contain a CpG dinucleotide (bold) in their core sequences (Fig. 6B). (c) 2020 The authors Published by Bioscientifica Ltd
This work is licensed under a Creative Commons Attribution-NonCommercial-NoDerivatives 4.0 International License.ifica com at $04 / 26 / 2023$ 12:04:49PM 

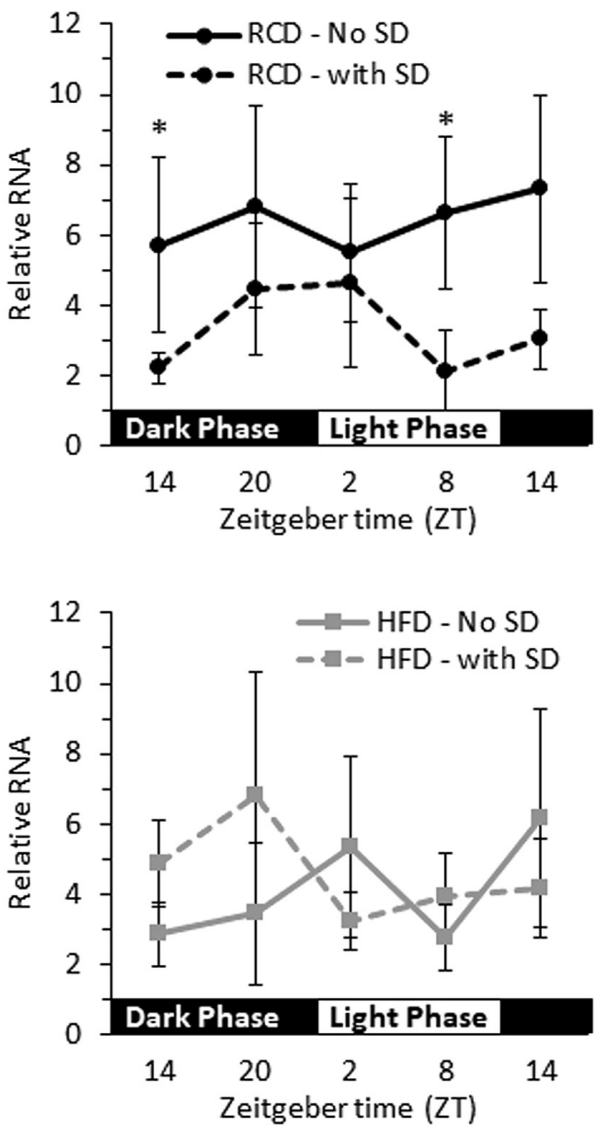

\section{Figure 5}

The effect of acute sleep deprivation (SD) on human (h) growth hormone (GH) RNA levels. Transcript levels were normalized to $\beta$-actin RNA and shown as relative RNA across a 24-h cycle beginning $2 \mathrm{~h}$ into the dark/ active phase (Zeitgeber time (ZT) 14=20:00 h). Black solid line represents regular chow diet (RCD) and gray solid line represents high-fat diet (HFD). Dashed lines represent \pm acute SD. $n=5$ per timepoint. Mean values and S.E.M. are shown. Ten single $t$-test comparisons were effectuated to compare no SD vs SD among the timepoints. Significance is represented by $* P<0.05$.

Bisulfite conversion and Illumina sequencing were used to assess the methylation status of $\mathrm{CpG}$ sites within the $h G H-N$ promoter and LCR HS II sequences in the 171hGH/CS TG mouse pituitary in situ, which include putative $h G H$ promoter E-box, and HS II E-box 1 and E-box 2 (Fig. 6). Ten CpG sites were identified within the $h G H-N$ promoter region $-494 /+1$, including promoter E-box that corresponds to CpG 8 (Fig. 7A). CpG 1 and CpG 8 were relatively hypomethylated compared to the other eight $\mathrm{CpG}$ sites under conditions of acute SD and diet (Fig. 7A). Among CpG 8, no considerable effect was observed for acute SD, however, a 1.8-fold decrease in CpG methylation in HFD vs RCD was observed during the light/inactive phase (Fig. 8A). Ten CpG sites were identified in the LCR HS II sequence where CpG 1 is found in putative HS II E-box 1 and CpG 4 is found in HS II E-box 2 (Figs 6 and 7B). CpG 4 was relatively hypomethylated under all conditions of acute SD and diet, relative to other sites including CpG 1 (Fig. 7b). Among CpG 4, no clear effect was observed for acute SD in mice fed a HFD, however acute SD was associated with 1.3-fold and 1.7-fold increases in methylation in the dark/active and light/inactive phases (respectively) in mice fed a RCD (Fig. 8B). A 1.6-fold and 1.3-fold increase in methylation in the dark/active and light/inactive phases (respectively) was also observed in mice fed a HFD vs RCD (Fig. 8B).

The effect of $\mathrm{CpG}$ methylation in the core sequences of HS II E-box 1 and E-box 2 as well as $h G H-N$ promoter E-box, on clock-related E-box factor binding was assessed by EMSA. This was done using unmethylated vs methylated radiolabeled oligonucleotide probes (Table 2) with nuclear extract enriched in BMAL1/CLOCK proteins (Fig. 9). A low mobility complex that increased in intensity with BMAL1/CLOCK overexpression was detected using unmethylated HS II E-box 1 oligonucleotide. A series of at least four low to high mobility complexes were detected using unmethylated $h G H-N$ promoter E-box (thick arrow, Fig. 9, Lane 3), including a major complex with a mobility comparable to the predominant low mobility complex seen using unmethylated HS II E-box 1 as a probe (thick arrow, Fig. 9, Lane 9). However, these low mobility complexes related to Bmal1/Clock overexpression were decreased in intensity (Fig. 9, Lane 6) or absent (Fig. 9 Lane 12) when methylated $h G H-N$ promoter E-box and HS II E-box 1 were used as probes. By contrast, there was little evidence of binding to unmethylated HS II E-box 2 (thin arrow, Fig. 9, Lanes 14 and 15), however, a low mobility complex was detected with greater intensity when methylated HS II E-box 2 was used as a probe (thin arrow, Fig. 9, Lanes 17 and 18).

\section{Discussion}

Based on studies using partially humanized $171 \mathrm{hGH} / \mathrm{CS}$ TG mice, evidence is presented that supports extending a negative effect of acute SD on hGH production at the level of synthesis, and more specifically $h G H-N$ RNA accumulation. For the first time, these mice expressing $h G H-N$ in a pituitary-specific and rhythmic manner were used to assess the effect of acute SD on $h G H-N$ RNA levels in active and inactive phases of the daily cycle, based on conservation of clock-related transcription factors and thus circadian rhythm machinery in mammals (36). 


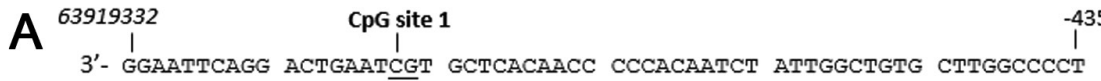

TTTCCCAACA CACACATTCT GTCTGGTGGg TGGAGGTTAA ACATGCGGGg AGGAgGAAAG

GGATAgGATA GAGAATGGGA TGTGGTCGGT AgGGGGTCTC AAgGACTGGC TATCCTGACA

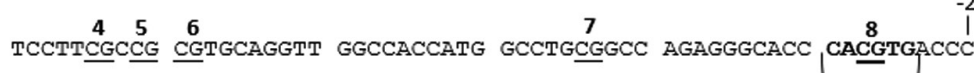

Putative E-box Element

TTAAAGAGAG GACAAGTTGG GTGGTATCTC TGGCTGACAC TCTGTGCACA ACCCTCACAA

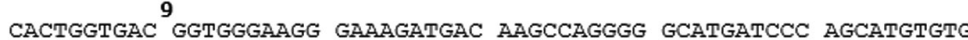

ggaggagctT ctaAattatc cattagcaca agccCGTcag tggccccatg cataAatgta

TATA box

CACAGAAACA GGTGGGGTCA ACAGTGGGAG AGAAGGGGCC AGGGTATAAA AAGGGCCCAC

AAGAGACCAG CTCAAGGATC $\stackrel{-1}{\mathrm{C}}-5^{\prime}$

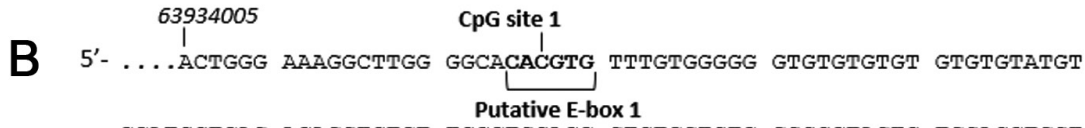

GCATGCTCAC ACAGGTGTGT TGCCTGGACC CTGTGGTGTG GGGCCTACTC TGGAGCTGGT

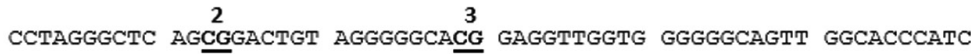

..610bp...GCCCAGGTGT CCTGGATCTG CTGGGCTGCT GTGACTGGGA AAAGACCTGC

taAgatagac 4 gtgggttiga gtcctgaccc agcagtgtag cagccagga acctccccag

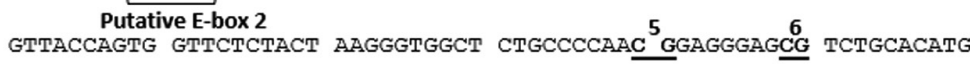

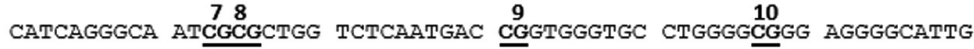

GCTGGCAAAG CAGAGTTCCC TGCCCCACAT GCCAACAGCA CCCATGAGGC AACACCCATT

CTTAACCTCT CAGTGACCAA GGTTCCTCAT TTTCGTAAAA TAGAAATAAG CCCAATAGCG 63935185

CGTTTTTTt TTGTTGTTT CTGGGGTTTT TCTGAGACAA GATCT -3 '

\section{Figure 6}

(A) Human growth hormone gene promoter region sequence (negative strand; $501 \mathrm{bp}$; chr17: 63918832-63919332), and (B) locus control region hypersensitive site II sequence (positive strand; 1181 bp; chr17: 63934005-63935185). Identified CpG (cytosine next to guanine) sites with methylation status are underlined. Putative E-box DNA elements are in bold and identified. TATA box is also in bold.
The possible influence of HFD was also explored as well as the potential for DNA methylation to affect clock-related transcription factor binding. To our knowledge, this is the first study to use a murine system to observe the effect of SD on hGH synthesis, as studies on $h G H-N$ RNA levels in the pituitary are not possible in living humans. As expected, the consumption of a HFD for 3-4 days did not cause significant weight gain $(12,13)$, but there was evidence of stress due to acute SD that was independent of diet. SD was associated with significant weight reduction and stimulated food intake. A clear trend toward increases in serum corticosterone levels as well as decreased insulin were also detected. Stress is expected to increase glucocorticoid levels in mice (37), and lower insulin presumably contributes to maintenance of glucose or energy levels under the stress of SD. Glucocorticoids have been shown to increase GH levels $(38,39,40)$, as well as in the context of HFD in vitro (41). Glucocorticoids are also involved in circadian rhythms by activating transcription factors through their binding at glucocorticoid response elements within genes, and are themselves subject to circadian control $(42,43)$.

Expression of circadian rhythm transcription factor genes, Bmal1, Clock, Cry 1, and Per 2, were assessed every $6 \mathrm{~h}$ over $24 \mathrm{~h}$, beginning $2 \mathrm{~h}$ into the dark/active phase at ZT 14 in both HFD and RCD mice. Opposing oscillations of Bmal1 and Per2 RNA levels were seen with a peak and trough in the light/inactive period, respectively, consistent with the presence of a daily cycle in the mouse pituitary. Mouse brain Per2 expression is known to be sensitive to SD and time of day $(19,20)$. This response appears to extend to the pituitary, as SD caused significant decreases in Per2 RNA levels, which was independent of diet. There was also an observed (but not significant) 
A
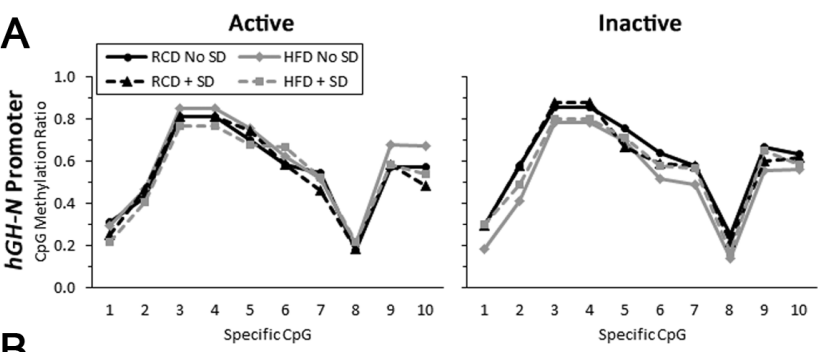

B

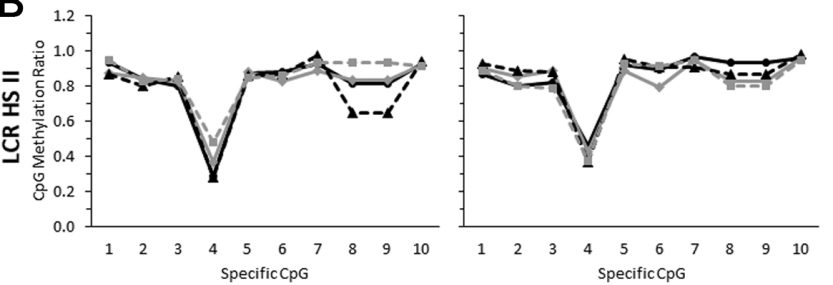

Figure 7

Bisulfite conversion and Illumina sequencing of DNA extracted from mouse pituitary samples by acute sleep deprivation (SD) as well as by regular control chow diet (RCD) or high-fat diet (HFD). The methylation status of ten CpG dinucleotides was identified in (A) the $h G H-N$ promoter sequence as well as in (B) the locus control region (LCR) hypersensitive site II (HS II). hGH-N promoter CpG 1 and CpG 8 as well as LCR HS II CpG 4 demonstrated hypomethylation. Mean CPG methylation ratios are shown which represent the number of methylated CpGs over total CpGs. $n=2$ per CpG.

decrease of Bmal1 RNA levels among HFD mice only in the dark/active phase, which is consistent with a negative effect of BMAL1/CLOCK heterodimer availability reported previously in mouse brain following SD (21). A decrease in BMAL1 availability would be expected to result in decreased $h G H-N$ promoter activity (13).

Acute SD resulted in significant decreases in $h G H-N$ but not $m G h$ RNA accumulation in RCD mice, which was independent of assessment in the light/inactive or dark/ active phase of the daily cycle. This is consistent with a negative effect of acute SD on hGH synthesis as well as secretion (4). A comparable decrease in $h G H-N$ RNA levels was also seen with HFD vs RCD in the dark/active phase of the daily cycle. These effects of acute SD and HFD do not appear to be additive as there was no further decrease in $h G H-N$ RNA levels with SD for HFD mice. This would also be consistent with both SD and HFD impacting $h G H-N$ expression through a common pathway. Previously, the lack of response of endogenous $m G h$ to HFD was used to support the possible involvement of an E-box element that is present at nucleotides $-264 /-259$ in the promoter region of $h G H-N$ but not $m G h(13,34)$. Similarly, $m G h$ RNA levels were not affected significantly by acute SD. Thus, given the similarity of response to SD and HFD and no evidence of an additive effects, it is possible that

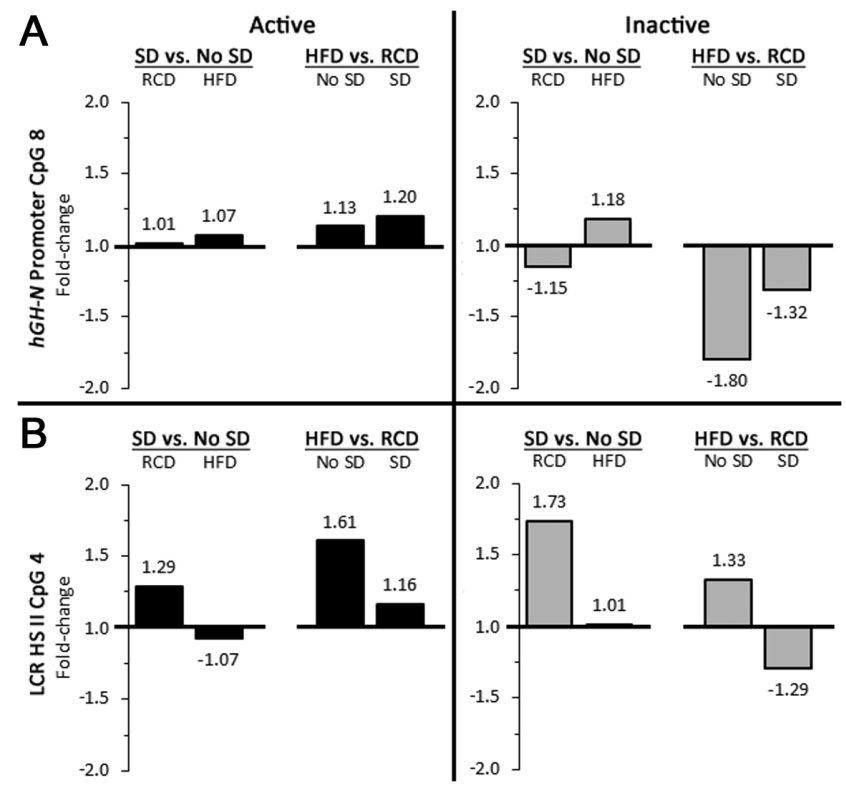

Figure 8

Fold-effects of acute sleep deprivation (SD) and diet on (A) the $h G H-N$ promoter CpG 8, as well as (B) the locus control region (LCR) hypersensitive site II (HS II) CpG 4 which are located within the BMAL1/ CLOCK E-box binding element. CpG methylation fold-change is shown by acute SD (SD vs No SD) as well as by high-fat diet (HFD) (HFD vs Regular Chow Diet (RCD)) in both the dark/active and light/inactive phases (respectively). A fold increase is represented by a positive number (black fill) while a fold decrease is represented by a negative number (white fill).

the $h G H-N$ promoter E-box element represents a target of both SD and HFD. The presence of this E-box element may explain the difference in the response of hGH and mGH genes observed, in spite of the common pituitary (nuclear transcription factor) environment (44). The presence of this E-box element would also explain why both $h G H-N$ and $m G h$ gene expression are negatively regulated by insulin in the same $171 \mathrm{hGH} / \mathrm{CS}$ TG mouse pituitary cells, but $h G H-N$ appears to be more sensitive to insulin levels possibly via an additional independent mechanism (34).

Human GH-N RNA levels demonstrated variability between mice when assessed over a 24 -h period. RCD mice did not demonstrate a $h G H$ RNA peak and trough at ZT 2 and ZT 14, respectively, as previously reported (13); however, a similar oscillation in $h G H$ synthesis was suggested with acute SD in RCD but not HFD mice. This may reflect a synchronizing effect of SD on the diurnal cycle in mice on RCD that is also disrupted by HFD.

Bisulfite conversion and Illumina sequencing identified methylated $\mathrm{CpG}$ dinucleotides located within the $h G H-N$ promoter E-box element at nucleotides
This work is licensed under a Creative Commons Attribution-NonCommercial-NoDerivatives 4.0 Internationab dicense.ifica.com at 04/26/2023 12:04:49PM 

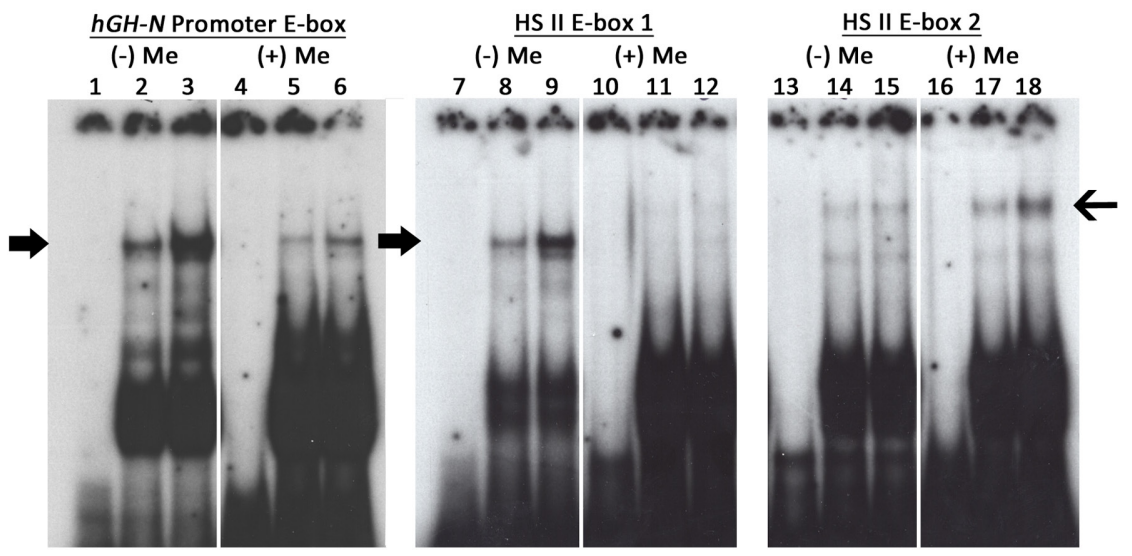

\section{Figure 9}

EMSA results using (-) Me (unmethylated) and (+) $\mathrm{Me}$ (methylated) oligonucleotides (probes) for putative BMAL1/CLOCK E-box DNA binding element in the $h G H-N$ promoter and putative E-box 1 and E-box 2 in locus control region (LCR) hypersensitive site II upstream of $h \mathrm{GH}-\mathrm{N}$ promoter. Lanes 1, 4, 7, 10, 13, and 16 represent free probe/radioactive oligonucleotides only, lanes 2, 5, 8, 11, 14, and 17 represent nuclear extract from HEK293 cell transfected with an empty vector and lanes $3,6,9,12,15$, and 18 represent nuclear extract from HEK293 overexpressing BMAL1/CLOCK. Arrows point to the low mobility DNA bound by protein complexes.

-264/-259, but also related putative E-box-like elements 1 and 2 within HS II (HS II E-box 1 and E-box 2). The core E-box hexanucleotide sequence (5'-CACGTG-3') containing a central CpG is identical in both $h G H-N$ promoter E-box and HS II E-box 1, however, only $h G H-N$ promoter E-box CpG was relatively hypomethylated. By contrast, the core sequence of HS II E-box 2, which shares five of six nucleotides with the core of $h G H-N$ promoter E-box, was also relatively hypomethylated. However, while a decrease in the CpG methylation ratio at $h G H-N$ promoter E-box was suggested during the light/inactive phase in HFD mice, the opposite effect (increased ratio) was suggested at HS II E-box 2 in the dark/active and light/inactive phases. In addition, when the data are re-plotted to assess fold-effects of acute SD in the absence of HFD at a specific CpG, an increase in CpG methylation of the HS II E-box 2 sequence is also suggested in both the dark/active and light/inactive phases among RCD. Thus, a trend toward increased CpG methylation within HS II E-box 2 sequences correlates with the common decrease in $h G H-N$ RNA levels suggested with acute SD and HFD in $171 \mathrm{hGH} / \mathrm{CS}$ TG mice.

Interestingly, while an increase in $\mathrm{CpG}$ methylation of $h G H-N$ promoter E-box was associated with decreased binding of nuclear protein from HEK293 cells overexpressing Bmal1/Clock, an increase in binding was detected with HS II E-box 2 sequences under the same conditions. HS I/II represents a pituitary enhancer region (31) and when methylated, would be expected to repress gene expression since $\mathrm{CpG}$ dinucleotides located in a gene body typically leads to increased gene expression while CpGs located in promoters or enhancers leads to transcriptional silencing in the case of hypermethylation (23). However, in addition to changing the chemical signature of CpGs to regulate gene expression, cytosine methylation can also affect DNA structure $(23,45)$.
Direct contact of a protein to a methyl group could obliterate or improve binding through formation or alteration of van der Waals interactions (45). Therefore, CpG methylation could very well enhance transcription factor binding and evoke changes to chromatin to facilitate or repress gene expression. Interestingly, a recent study has shown CCAAT/enhancer-binding protein $\beta$ binds the sequence 5'-TTGCGCAA-3' with greater affinity when the central CpG dinucleotide (underlined) is methylated relative to the unmodified sequence in vitro (46). A role for DNA methylation also complements previous studies implicating epigenetic control through posttranslational modification of histones, including acetylation and methylation, in the regulation of $h G H-N$ expression (33, $47,48,49,50)$.

Taken together, this is the first report that $\mathrm{hGH}$ synthesis is negatively affected by acute SD, and that DNA methylation may play a role in regulating $h G H-N$ expression through increased methylation at a central CpG in a putative E-box (5'-CAGTG-3') within the hGH LCR at HS II in situ, which in turn increases protein-DNA binding in vitro.

\section{Declaration of interest}

The authors declare that there is no conflict of interest that could be perceived as prejudicing the impartiality of the research reported.

\section{Funding}

This work was supported by a grant to P A C from the Canadian Institutes of Health Research (FRN-166215). P A C holds the H.G. Friesen Chair in Endocrine \& Metabolic Disorders.

\section{Acknowledgements}

The author would like to thank Margaret E Bock for administrative support and Ian McNicol for technical assistance. 


\section{References}

1 Wideman L, Weltman JY, Hartman ML, Veldhuis JD \& Weltman A. Acute and chronic aerobic and recent findings. Sports Medicine 2002 32 987-1004. (https://doi.org/10.2165/00007256-200232150-00003)

$2 \mathrm{Li} \mathrm{CH} \&$ Evans HM. The isolation of pituitary growth hormone. Science 194499 183-184. (https://doi.org/10.1126/ science.99.2566.183)

3 Steyn FJ \& Ngo ST. Endocrine rhythms of growth hormone release: insights from animal studies. Best Practice and Research: Clinical Endocrinology and Metabolism 201731 521-533. (https://doi. org/10.1016/j.beem.2017.10.009).

4 Brandenberger G, Gronfier C, Chapotot F, Simon C \& Piquard F. Effect of sleep deprivation on overall $24 \mathrm{~h}$ growth-hormone secretion. Lancet 2000356 1408. (https://doi.org/10.1016/S01406736(00)02847-6)

5 Lieb K, Reincke M, Riemann D \& Voderholzer U. Sleep deprivation and growth-hormone secretion. Lancet 2000356 2096-2097. (https://doi.org/10.1016/S0140-6736(05)74304-X)

6 Rasmussen MH, Wildschiødtz G, Juul A \& Hilsted J. Polysomnographic sleep, growth hormone insulin-like growth factor-I axis, leptin, and weight loss. Obesity 200816 1516-1521. (https://doi.org/10.1038/oby.2008.249)

7 Salvatori R. Growth hormone deficiency in patients with obesity. Endocrine 201549 304-306. (https://doi.org/10.1007/s12020-0150571-4).

8 Naidoo N, Davis JG, Zhu J, Yabumoto M, Singletary K, Brown M, Galante R, Agarwal B \& Baur JA. Aging and sleep deprivation induce the unfolded protein response in the pancreas: implications for metabolism. Aging Cell 201413 131-141. (https://doi.org/10.1111/ acel.12158)

9 Ilias I, Vgontzas AN, Provata A \& Mastorakos G. Complexity and non-linear description of diurnal cortisol and growth hormone secretory patterns before and after sleep deprivation. Endocrine Regulations 200236 63-72.

10 Cattini PA, Bock ME, Jin Y, Zanghi JA \& Vakili H. A useful model to compare human and mouse growth hormone gene chromosomal structure, expression and regulation, and immune tolerance of human growth hormone analogues. Growth Hormone and IGF Research 2018 42-43 58-65. (https://doi.org/10.1016/j. ghir.2018.09.001).

11 Jin Y, Lu SY, Fresnoza A, Detillieux KA, Duckworth ML \& Cattini PA. Differential placental hormone gene expression during pregnancy in a transgenic mouse containing the human growth hormone/ chorionic somatomammotropin locus. Placenta 200930 226-235. (https://doi.org/10.1016/j.placenta.2008.12.011)

12 Vakili H, Jin Y \& Cattini PA. Energy homeostasis targets chromosomal reconfiguration of the human GH1 locus. Journal of Clinical Investigation 2014124 5002-5012. (https://doi.org/10.1172/ JCI77126)

13 Vakili H, Jin Y \& Cattini PA. Evidence for a circadian effect on the reduction of human growth hormone gene expression in response to excess caloric intake. Journal of Biological Chemistry 2016291 13823-13833. (https://doi.org/10.1074/jbc.M116.722744)

14 Kohsaka A, Laposky AD, Ramsey KM, Estrada C, Joshu C, Kobayashi Y, Turek FW \& Bass J. High-fat diet disrupts behavioral and molecular circadian rhythms in mice. Cell Metabolism 20076 414-421. (https://doi.org/10.1016/j.cmet.2007.09.006)

15 Hatori M, Vollmers C, Zarrinpar A, DiTacchio L, Bushong EA, Gill S, Leblanc M, Chaix A, Joens M, Fitzpatrick JAJ, et al. Time-restricted feeding without reducing caloric intake prevents metabolic diseases in mice fed a high-fat diet. Cell Metabolism 201215 848-860. (https://doi.org/10.1016/j.cmet.2012.04.019)

16 Deboer T. Sleep homeostasis and the circadian clock: do the circadian pacemaker and the sleep homeostat influence each other's functioning? Neurobiology of Sleep and Circadian Rhythms 20185 68-77. (https://doi.org/10.1016/j.nbscr.2018.02.003).

17 Patke A, Young MW \& Axelrod S. Molecular mechanisms and physiological importance of circadian rhythms. Nature Reviews: Molecular Cell Biology 202021 67-84. (https://doi.org/10.1038/ s41580-019-0179-2).

18 Franken P. A role for clock genes in sleep homeostasis. Current Opinion in Neurobiology 201323 864-872. (https://doi.org/10.1016/j. conb.2013.05.002).

19 Curie T, Mongrain V, Dorsaz S, Mang GM, Emmenegger Y \& Franken P. Homeostatic and circadian contribution to EEG and molecular state variables of sleep regulation. Sleep 201336 311-323. (https://doi.org/10.5665/sleep.2440)

20 Mongrain V, Hernandez SA, Pradervand S, Dorsaz S, Curie T, Hagiwara G, Gip P, Heller HC \& Franken P. Separating the contribution of glucocorticoids and wakefulness to the molecular and electrophysiological correlates of sleep homeostasis. Sleep 2010 33 1147-1157. (https://doi.org/10.1093/sleep/33.9.1147)

21 Mongrain V, La Spada F, Curie T \& Franken P. Sleep loss reduces the DNA-binding of BMAL1, CLOCK and NPAS2 to specific clock genes in the mouse cerebral cortex. PLoS ONE 20116 e26622. (https://doi. org/10.1371/journal.pone.0026622)

22 Beccuti G \& Pannain S. Sleep and obesity. Current Opinion in Clinical Nutrition and Metabolic Care 201114 402-412. (https://doi. org/10.1097/MCO.0b013e3283479109)

23 Jang HS, Shin WJ, Lee JE \& Do JT. CpG and non-CpG methylation in epigenetic gene regulation and brain function. Genes 20178 2-20. (https://doi.org/10.3390/genes8060148)

24 Milagro FI, Gómez-Abellán P, Campión J, Martínez JA, Ordovás JM \& Garaulet M. CLOCK, PER2 and BMAL1 DNA methylation: association with obesity and metabolic syndrome characteristics and monounsaturated fat intake. Chronobiology International 201229 1180-1194. (https://doi.org/10.3109/07420528.2012.719967)

25 Bhatti P, Zhang Y, Song X, Makar KW, Sather CL, Kelsey KT, Houseman EA \& Wang P. Nightshift work and genome-wide DNA methylation. Chronobiology International 201532 103-112. (https:// doi.org/10.3109/07420528.2014.956362)

26 Skuladottir GV, Nilsson EK, Mwinyi J \& Schiöth HB. One-night sleep deprivation induces changes in the DNA methylation and serum activity indices of stearoyl-CoA desaturase in young healthy men. Lipids in Health and Disease 201615 137. (https://doi.org/10.1186/ s12944-016-0309-1)

27 He F, Berg A, Imamura Kawasawa Y, Bixler EO, Fernandez-Mendoza J, Whitsel EA \& Liao D. Association between DNA methylation in obesity-related genes and body mass index percentile in adolescents. Scientific Reports 20199 2079. (https://doi.org/10.1038/s41598-01938587-7)

28 Tan HY, Huang L, Simmons D, Veldhuis JD, Steyn FJ \& Chen C. Hypothalamic distribution of somatostatin mRNA expressing neurones relative to pubertal and adult changes in pulsatile growth hormone secretion in mice. Journal of Neuroendocrinology 201325 910-919. (https://doi.org/10.1111/jne.12078)

29 Patti CL, Zanin KA, Sanday L, Kameda SR, Fernandes-Santos L, Fernandes HA, Andersen ML, Tufik S \& Frussa-Filho R. Effects of sleep deprivation on memory in mice: role of state-dependent learning. Sleep 201033 1669-1679. (https://doi.org/10.1093/sleep/33.12.1669)

30 Franken P, Dijk DJ, Tobler I \& Borbely AA. Sleep deprivation in rats: effects on EEG power spectra, vigilance states, and cortical temperature. American Journal of Physiology 1991261 R198-R208. (https://doi.org/10.1152/ajpregu.1991.261.1.R198)

31 Jin Y, Surabhi RM, Fresnoza A, Lytras A \& Cattini PA. A role for A/T-rich sequences and Pit-1/GHF-1 in a distal enhancer located in the human growth hormone locus control region with preferential pituitary activity in culture and transgenic mice. Molecular Endocrinology 199913 1249-1266. (https://doi.org/10.1210/ mend.13.8.0332) https://ec.bioscientifica.com https://doi.org/10.1530/EC-20-0354
(C) 2020 The authors Published by Bioscientifica Ltd
This work is licensed under a Creative Commons Attribution-NonCommercial-NoDerivatives 4.0 Internationab ficense.ifica . com at 04/26/2023 12:04:49PM 
32 Langmesser S, Tallone T, Bordon A, Rusconi S \& Albrecht U. Interaction of circadian clock proteins PER2 and CRY with BMAL1 and CLOCK. BMC Molecular Biology 20089 41. (https://doi. org/10.1186/1471-2199-9-41)

33 Ho Y, Tadevosyan A, Liebhaber SA \& Cooke NE. The juxtaposition of a promoter with a locus control region transcriptional domain activates gene expression. EMBO Reports 20089 891-898. (https:// doi.org/10.1038/embor.2008.126)

34 Vakili H, Jin Y \& Cattini PA. Negative regulation of human growth hormone gene expression by insulin is dependent on hypoxiainducible factor binding in primary non-tumor pituitary cells. Journal of Biological Chemistry 2012287 33282-33292. (https://doi. org/10.1074/jbc.M112.380949)

35 Shewchuk BM, Ho Y, Liebhaber SA \& Cooke NE. A single base difference between Pit-1 binding sites at the hGH promoter and locus control region specifies distinct Pit-1 conformations and functions. Molecular and Cellular Biology 200626 6535-6546. (https:// doi.org/10.1128/MCB.00267-06)

36 King DP \& Takahashi JS. Molecular Genetics of circadian rhythms in mammals. Annual Review of Neuroscience 200023 713-742. (https:// doi.org/10.1146/annurev.neuro.23.1.713)

37 Cohen S, Kozlovsky N, Matar MA, Kaplan Z, Zohar J \& Cohen H. Post-exposure sleep deprivation facilitates correctly timed interactions Between glucocorticoid and adrenergic systems, which attenuate traumatic stress responses. Neuropsychopharmacology 2012 37 2388-2404. (https://doi.org/10.1038/npp.2012.94)

38 Chen C, Nakagawa S, An Y, Ito K, Kitaichi Y \& Kusumi I. The exercise-glucocorticoid paradox: how exercise is beneficial to cognition, mood, and the brain while increasing glucocorticoid levels. Frontiers in Neuroendocrinology 201744 83-102. (https://doi. org/10.1016/j.yfrne.2016.12.001)

39 Kanaley JA, Weltman JY, Pieper KS, Weltman A \& Hartman ML. Cortisol and growth hormone responses to exercise at different times of day 1. Journal of Clinical Endocrinology and Metabolism 200186 2881-2889. (https://doi.org/10.1210/jcem.86.6.7566)

40 Droste SK, Gesing A, Ulbricht S, Müller MB, Linthorst ACE \& Reul JMHM. Effects of long-term voluntary exercise on the mouse hypothalamic-pituitary-adrenocortical axis. Endocrinology 2003144 3012-3023. (https://doi.org/10.1210/en.2003-0097)

41 Vakili H, Jin Y, Nagy JI \& Cattini PA. Transgenic mice expressing the human growth hormone gene provide a model system to study human growth hormone synthesis and secretion in non-tumorderived pituitary cells: differential effects of dexamethasone and thyroid hormone. Molecular and Cellular Endocrinology 2011345 48-57. (https://doi.org/10.1016/j.mce.2011.07.010).

42 Lamia KA, Papp SJ, Yu RT, Barish GD, Uhlenhaut NH, Jonker JW, Downes M \& Evans RM. Cryptochromes mediate rhythmic repression of the glucocorticoid receptor. Nature $2011480552-556$. (https://doi.org/10.1038/nature10700)

43 Cheon S, Park N, Cho S \& Kim K. Glucocorticoid-mediated Period2 induction delays the phase of circadian rhythm. Nucleic Acids Research 201341 6161-6174. (https://doi.org/10.1093/nar/gkt307)

44 Xu J, Sun D, Jiang J, Deng L, Zhang Y, Yu H, Bahl D, Langenheim JF, Chen WY, Fuchs SY, et al. The role of prolactin receptor in GH signaling in breast cancer cells. Molecular Endocrinology 201327 266-279. (https://doi.org/10.1210/me.2012-1297)

45 Rao S, Chiu TP, Kribelbauer JF, Mann RS, Bussemaker HJ \& Rohs R. Systematic prediction of DNA shape changes due to CpG methylation explains epigenetic effects on protein-DNA binding. Epigenetics and Chromatin 201811 6. (https://doi.org/10.1186/ s13072-018-0174-4).

46 Yang J, Horton JR, Wang D, Ren R, Li J, Sun D, Huang Y, Zhang X, Blumenthal RM \& Cheng X. Structural basis for effects of CpA modifications on C/EBP binding of DNA. Nucleic Acids Research 2019 47 1774-1785. (https://doi.org/10.1093/nar/gky1264)

47 Ho Y, Elefant F, Cooke N \& Liebhaber S. A defined locus control region determinant links chromatin domain acetylation with longrange gene activation. Molecular Cell 20029 291-302. (https://doi. org/10.1016/s1097-2765(02)00447-1)

48 Ho Y, Liebhaber SA \& Cooke NE. Activation of the human GH gene cluster: roles for targeted chromatin modification. Trends in Endocrinology and Metabolism 200415 40-45. (https://doi. org/10.1016/j.tem.2003.11.004)

49 Kimura AP, Liebhaber SA \& Cooke NE. Epigenetic modifications at the human growth hormone locus predict distinct roles for histone acetylation and methylation in placental gene activation. Molecular Endocrinology 200418 1018-1032. (https://doi.org/10.1210/me.20030468)

50 Cattini PA, Yang X, Jin Y \& Detillieux KA. Regulation of the human growth hormone gene family: possible role for Pit-1 in early stages of pituitary-specific expression and repression. Neuroendocrinology 2006 83 145-153. (https://doi.org/10.1159/000095522)

Received in final form 9 October 2020

Accepted 13 October 2020

Accepted Manuscript published online 13 October 2020 https://ec.bioscientifica.com https://doi.org/10.1530/EC-20-0354
(C) 2020 The authors Published by Bioscientifica Ltd
This work is licensed under a Creative Commons Attribution-NonCommercial-NoDerivatives 4.0 International License.ifica com at $04 / 26 / 2023$ 12:04:49PM 